Pace University

DigitalCommons@Pace

Pace Law Faculty Publications

School of Law

2010

\title{
A Little More Mascara: Response to Making Up Is Hard to Do
}

Darren Rosenblum

Elisabeth Haub School of Law at Pace University

Follow this and additional works at: https://digitalcommons.pace.edu/lawfaculty

Part of the Law and Gender Commons, and the Sexuality and the Law Commons

\section{Recommended Citation}

Darren Rosenblum, A Little More Mascara: Response to Making Up Is Hard to Do, 33 Harv. J. L. \& Gender 59 (2010), http://digitalcommons.pace.edu/lawfaculty/732/.

This Article is brought to you for free and open access by the School of Law at DigitalCommons@Pace. It has been accepted for inclusion in Pace Law Faculty Publications by an authorized administrator of DigitalCommons@Pace. For more information, please contact dheller2@law.pace.edu. 


\title{
A LITTLE MORE MASCARA: RESPONSE TO MAKING UP IS HARD TO DO
}

\author{
DARREN ROSENBLUM*
}

\section{Dear Adrienne and Bob:}

First, thanks for including me in this written conversation. For those who don't know you both, I should say that your conversation is actually very queer. Bob, your resistance to saying you're straight means more when one can see how you present yourself. Few men in the U.S. come across as ambiguously as you do, so your refusal to claim straight privilege really means something. Adrienne, for someone who doesn't know you, your shopping-talk may seem more Kim Kardashian-consumerist than it is-I think it's more about your incessant fabulousness. Now, to connect who you are to who I am. I suspect that you asked me to join the conversation because, well, I'm a big girl myself. Like many gay men, I'm effeminate. Unlike many effeminate gay men, I'm rarely seen "butching it up" or overcompensating for my femininity.

Drag has always been an inspiration, a distortion, and resistance to mainstream life rather than a reification of it. On paper, I'm a nice Jewish lawyer from Long Island, but I began to find myself through the friends I met at Gay and Lesbian Youth of New York (GLYNY) in the mid-1980s. Almost all were working and middle class black and Latino gay boys, and several participated in the ball culture profiled in Jennie Livingston's 1990 film Paris is Burning.' Lacking the class privileges, or even family support from which I benefited, they nonetheless evinced an indomitable instinct for thriving amidst adversity. Since my weekdays were filled with bullying, Saturdays were a lifeline that nourished in me an appreciation for my little queer self. After meetings at the LGBT Community Center, some of the kids would practice walking with the late Willi Ninja, ${ }^{2}$ and then we'd go out to dinner or to hang out on the Christopher Street pier.

* Professor, Pace Law School. Thanks to Bob Chang, Adrienne Dale Davis, and Daria Roithmayr for their invaluable comments. Thanks to my invaluable research assistants Hilary C. Atkin, Matthew Collibee, and Nicholas W. Tapert.

' PARIS is Burning (Miramax 1990). The documentary chronicled the ball culture, an LGBT subculture in New York in which relatively marginalized African American and Latino LGBT individuals participate in drag competitions to test the "realness" of their "drag." See id.

${ }^{2} I d$. Willi features prominently in Paris is Burning. He died in 2006. Lola Ogunnaike, Willi Ninja, 45, Self-Created Star Who Made Vogueing into an Art, N.Y. Times, Sept. 6, 2006, at D8. Mary Anne Case has an interesting comment about the film. See Mary Anne Case, Unpacking Package Deals: Separate Spheres Are Not the Answer, 75 Denver U. L. Rev. 1305, $1308 \mathrm{n} .17$ (1998) (discussing the role of house mothers in the ballroom scene and the feminist implications of "mothers [who] are genetic males flourishing in a subculture that glories in their effeminacy."). 
It's this part of me that comes out when I read your piece. I think about who I really am and how I perform in the classroom. Like anyone who grew up as an outcast queer kid, I experience gender identity in a regularly contested fashion. I think it, and rethink it, with every outfit.

Scholars you reference, Carbado and Gulati in particular, give voice to your concerns about both your gender performances. ${ }^{3}$ Their theories are apt and useful but don't quite capture how fragile the balance is for those of us who are constantly aware of our precarious place. Gowri Ramachandran, in contrast, does discuss how gender performance can turn on a dime, with real consequences. Ramachandran states:

When a lawyer wears makeup, high heels, and a skirt, she might be performing a normative, heterosexual identity at work ... . But without changing a single aspect of her appearance, she may transform the meaning of that performance simply by going to a lesbian bar after work, where her ultra-femme look might take on an ironic meaning or signify participation in the lesbian butch-femme culture-a practice which is not only not normative, but is, like drag, deeply subversive of normative gender identities. And what if she is out of the closet at work? What if her coworkers know that she is a lesbian and know that she dresses in an ultra-femme manner? Is she "covering" her lesbian identity, making it easy for her coworkers to disattend it? Perhaps. But she might also be doing something rather subversive with her dress, even "flaunting" her femme role-playing behavior. She may even be having it both ways: "flaunting" her femme lesbian identity to coworkers who get it and "covering" her lesbian identity to coworkers who don't get it. ${ }^{4}$

The complexity of covering and flaunting, of performing marginality and privilege, all surfaces in the ball culture, where contestants win prizes for "realness," which is measured based on similarity to (outsider fantasies of) traditional gender performances. The "legends" of the ball succeed by proving their adeptness at these performances. I've done "realness," both while interviewing for an academic job and, more significantly, while practicing as a big firm lawyer for six years. ${ }^{5}$ "Realness" comes into play in the academic world, but we also must realize the extent to which we are all fortunate to function in a somewhat less conformity-driven field. As professors,

${ }^{3}$ Devon W. Carbado \& Mitu Gulati, Working Identity, 85 CoRnell L. Rev. 1259 (2000); see also Devon Carbado et al., The Jespersen Story: Makeup and Women at Work, in Employment Discrimination Stories (Joel W. Friedman ed., 2006); Devon Carbado, Straight Out of the Closet, 15 Berkeley WoMEN's L.J. 76 (2000).

${ }^{4}$ Gowri Ramachandran, Freedom of Dress: State and Private Regulation of Clothing, Hairstyle, Jewelry, Makeup, Tattoos, and Piercing, 66 MD. L. Rev. 11, 22-23 (2006).

${ }^{5}$ Dressing as a woman and going out in non-gay or mixed circles constitutes a less frequent, but very entertaining form of "realness" for me. 
we profit from the existence of spaces, places, and people where and with whom we can share the challenges of performing professorial "realness."

The story I want to share deals with the role of students who watch their professors work the front of the classroom (rather than the runway) and then mete out grades of these professors' performances like numbers in a ballroom competition. Like the ball queens, our competence is at stake in those numbers.

In my first semester as a professor at Pace Law School, I taught Criminal Law. Since the class was a seminar of only twenty-five students, I began my first class by discussing how critical participation was. I explained to the students that becoming a lawyer meant shedding the reluctance to speak publicly, and that practicing law would require answering questions posed by senior attorneys, even for non-litigators. I had no interest in humiliating my students and wanted to create an atmosphere in which everyone felt comfortable speaking. As an aside, I also mentioned that sometimes female students participated less because they felt more intimidated by the law school classroom. I conducted the class relatively informally, referring to students by their first names.

Then, I distributed grades on two assignments. On these assignments, the highest scoring students were female. Over the course of the semester, I noticed that one male student consistently answered questions incorrectly and another had an attitude when I called on him. I was ill-prepared for what then occurred.

I received my anonymous exams, and one of them was written in scribbled pink ink. It was far weaker than any other exam, and after much handwringing, I gave the student a "D." I suspected that the use of pink was some sort of reference, perhaps mocking, to my gay identity, as if I must be partial to pink. I declined to report the student to the honor board for breaking anonymity with the distinctive color pen. I thought the grade on the exam was punishment enough. It was indeed, as I was later informed that the student received only D's and ultimately withdrew from school.

Then I received my first student evaluations at my new school. Some glowed, others were mediocre, but two alleged that I had been biased in my grading:

His grading is extremely arbitrary and biased where the students believe the women overall received considerably higher grades (on the second assignment not one male received an A and only one female (that we found) received a failing grade. Professor Rosenblum is a very nice person, funny and smart but extremely out of line and seriously needs to be dealt with.

$\mathrm{He}$ is partial to woman [sic]. ${ }^{6}$

\footnotetext{
${ }^{6}$ Student Course Evaluations, Criminal Law/Rosenblum, Fall 2004.
} 
I immediately met with the Academic Dean, who dismissed my fears, concluding that the students were outliers. After meeting with some students early in the Spring semester, I learned that at least two of the male students thought that I gave better grades to female students. In fact, the first of the above comments indicates some collective effort on the part of men to determine the grades of other students. Of course, it is preposterous that I actually noticed the gender of the students as I graded their papers. ${ }^{7}$

I then understood the pink ink incident: another student told me that his classmate used pink ink to make me believe the student was a woman so that I would grade him more favorably. Later on, a male student came in and met with me after I invited feedback from the class. He proceeded to tell me how even though he paid me to teach him writing, I hadn't taught him. His diatribe seemed intended to demean me, and as a brand new faculty member, I took it passively.

The cabal that formed in this small section was made up of white men beset by fear. They were convinced that I had engaged in a group-based preference for the others, women. They feared that they would be eclipsed-convinced they were the best, they were shocked to learn that several women outperformed them. For the first time, they were in a class where women were smarter than them-they had to blame it on something else.

These incidents marked me in many ways. So, Bob, like you, there were rumors circulating, ${ }^{8}$ although unlike you, they insinuated that I favored women. As you suggest in your tale, it was an illogical rumor in a certain way. If the students think of me as gay, wouldn't a sexual harassment paradigm lead them to suspect me of favoring men, who would be the target of my affections? ${ }^{9}$ Or am I, as a gay man, an honorary woman, fiercer in my womanhood than any woman, to the point of overtly favoring women? Or is it that straight men envy the close relationship that gay men and straight women have? These questions still mystify me.

Here, for a moment, I think about the recent brouhaha over Congressman Joe Wilson's shouting "[y]ou lie" at President Obama during his

${ }^{7}$ I should note that although I believe this would be preposterous for me, other law professor colleagues may exhibit some gender bias in grading, perhaps even based on handwriting. Subsequent to my writing this piece, two students admitted to considering such tactics in a class as a response to a perceived favoring of female students by a heterosexual male professor. I should also note that the highest grade in the class went to a male student.

${ }^{8}$ Robert S. Chang \& Adrienne D. Davis, Making Up Is Hard to Do: Race/Gender/ Sexual Orientation in the Law School Classroom, 33 HARv. J. L. \& GENDER 1, 15-17 (2010).

${ }^{9}$ See Mary Coombs, Title VII and Homosexual Harassment After Oncale: Was it a Victory?, 6 Duke J. Gender L. \& PoL'y 113 (1999) (arguing that the expansion of sexual harassment law to include same-sex sexual harassment would likely lead to the use of sexual harassment law as a tool of straight men against gay men). 
speech to Congress on September 9, 2009. ${ }^{10}$ This is, in a way, an evaluation similar to those that teachers receive, and I think of it not only because our President is a former law professor. There was no secret as to who was opining. Nevertheless, it was a damning review of Obama. Was there bias in the evaluation? Undoubtedly, both Maureen Dowd and former President Carter persuasively argued..$^{11}$ Obama disagreed. ${ }^{12}$ What's wrong with calling it racism? Obama's reaction seems to move toward another goal. It's not about labeling racism, but about getting the racist to listen long enough to learn. Finger-wagging may alienate more than advance tolerance. Obama's cool reaction accepted that some opposition is from racist people in the United States, but that this opposition wasn't about race. This was a smart tactic because it deliberately attempted to defuse the situation and depolarize the debate. This technique, however, may not be available to those of us who cannot command press conferences on a whim.

Bob, I love your story of heterosexual privilege foregone. Nonetheless, as a first-year law professor, I feel as though I would have chosen the heterosexual privilege if it had been an option. Unfortunately, I did not know of the rumors that $I$ favored women until it was too late to fix it with that class. Perhaps I'm underestimating my performative abilities, but I don't think I can butch it up enough to overcome the many markers of gay identity on my faculty website, not to mention my usual self-presentation. In this sense, I felt trapped in a situation where a good number of my students might see me as an easy target. Would I indeed be as vulnerable as I was as a teenage queer kid subject to constant homophobic torment, despite the passing of decades and the acquisition of professional accomplishments? Once the class ended, I could not defuse the situation Obama-style. A class is a moment in time and space, and that space with those students had ceased to exist.

Bob, you talk about studies of responses to public speakers that reflect lower evaluations for openly gay speakers when the speaker performed well and more lenient judgments of lesbian and gay speakers when their presentations were poor. ${ }^{13}$ This suggests, as you point out, that sexual orientation and evaluation relate in more complex ways than simple bias. Indeed, as

${ }^{10}$ Carl Hulse, In Lawmaker's Outburst, a Rare Breach of Protocol, N.Y. Times, Sept. 10,2009 , at A26. To the delight of his brothers at the Sons of Confederate Veterans, in 2000 Wilson fought hard to keep the confederate flag flying high atop South Carolina's state capitol. Maureen Dowd, Boy, Oh, Boy, N.Y. TimES, Sept. 12, 2009, at WK17.

"Dowd, supra note 10; see also Posting of Kate Phillips to The Caucus, http://the caucus.blogs.nytimes.com/2009/09/16/carters-racism-charge-sparks-war-of-words/?scp= $1 \&$ sq $=$ carter\%20you\%20lie\&st $=$ search $($ Sept. 16, 2009, 11:51 EST).

${ }_{12}$ Posting of Jeff Zeleny to The Caucus, http://thecaucus.blogs.nytimes.com/2009/09/ 18/obama-says-race-is-not-the-overriding-issue-here/?scp $=2 \& \mathrm{sq}=$ obama $\% 20$ rejects $\% 20$ racism\&st $=$ search $($ Sept.18, 2009, 18:34 EST).

${ }^{13}$ Chang \& Davis, supra note 8, at 38-40; see also Therese A. Huston, Race and Gender Bias in Higher Education: Could Faculty Course Evaluations Impede Further Progress Toward Parity?, 4 Seattle J. for Soc. Justice 591 (2006); Kathleen Bean, The Gender Gap in the Law School Classroom-Beyond Survival, 14 VT. L. REv. 23 (1989); 
Deborah Merritt's recent work on bias in student evaluations suggests, although sexual orientation may not be fixed or visible, it is nonetheless identifiable. ${ }^{14}$ She references a study finding that undergraduates correctly identified another's sexual orientation about seventy percent of the time after viewing only ten seconds of silent videotape..$^{15}$ Given that study, all kinds of nonverbal cues may suggest sexual orientation identity. As Merritt says, "[i]f heterosexual students are uncomfortable with gays and lesbians, and they perceive a professor's homosexual orientation through his or her nonverbal behavior, that professor may receive more negative evaluations." 16 At the very least, the research Merritt cites suggests that bias may be a significant concern regarding sexual orientation. The conclusive nature of this research explains why I felt cornered.

And, Adrienne, this is where your discussion of "bottoming" comes in to play. ${ }^{17}$ You talk about how Asian men are effeminized or "bottomed," where "Asian and anus are conflated," 18 as the targets of the top. Their masculinity is robbed in a process that leaves Asian men as the target for disdain by those invested in white gender dichotomies.

As a gay man, the "bottom" term is no stranger to me. ${ }^{19}$ It applies perfectly in this context. I began my first semester at Pace thinking that I'd run a "nice" first year course-an egalitarian seminar. In a context where straight men yearn to be hazed in the masochistic ritual they have come to expect in the first year of law school, this must have struck them as exposing my weakness. Undoubtedly, my own nerves as a newbie played a part. They "bottomed" me, with the insulting pink ink, the mean and inaccurate evaluations, and the live berating that I largely accepted.

To help understand this situation and regain my sense of authority, I discussed this story in the LatCrit Faculty Development Workshop in the fall of 2005. There, Margaret Montoya held my hand as I processed and recovered. Looking back, it was not only Margaret who saved me-but I was so lucky to have a wise Academic Dean, Michelle Simon, with the experience to distinguish legitimate complaints from specious ones. The lessons that I drew from this incident were ones I undertook to protect myself from future role-flipping.

Christine Haight Farley, Confronting Expectations: Women in the Legal Academy, 8 YALE J.L. \& Feminism 333 (1996).

${ }^{14}$ Deborah J. Merritt, Bias, the Brain, and Student Evaluations of Teaching, 82 ST. JoHN's L. REv. 235, 259-60 (2008).

is Id. (citing Nalini Ambady et al., Accuracy of Judgments of Sexual Orientation from Thin Slices of Behavior, 77 J. Personaltry \& Soc. Psychol. 538, 541 (1999)).

${ }^{16}$ Id. at 260.

${ }^{17}$ Chang \& Davis, supra note 8, at 24-25.

${ }^{18}$ Id. at 24 (citing Richard Fung, Looking for My Penis: The Eroticized Asian in Gay Video Porn, in Asian American Studies: A Reader (Jean Yu-wen Shen Wu \& Min Song eds., 2000)).

${ }^{19} \mathrm{~A}$ common joke regarding men from my neighborhood in New York is "in Chelsea, you can't swing a dead cat without hitting a bottom." 
One lesson I drew related to the Socratic method. Like Adrienne, Pat Williams's Alchemy of Race and Rights: Diary of a Law Professor was a formative work for my intellectual life. ${ }^{20}$ Williams tells of renting an apartment in New York and how she relied on legal formalities, trusting less in more casual relationships because informality tended to leave her, as a black woman, unprotected. ${ }^{21}$ I felt likewise that my use of the students' first names, my efforts to engage in a more egalitarian classroom politics, and even my availability to the students only made them think of me as less than them. Perhaps one or two of the students were able to appreciate it, but it was at the high cost of coping with certain white men who thought less of me for my attempts. As you say you've become more formal in your writing, Adrienne, I feel I've become more formal in my first-year teaching.

After my first semester at Pace, I've found inspiration in friends who tell me of their strictness in the first-year classes. Over time since I began to teach Contracts in 2006, I've found that the more rigid I am, the more responsive and respectful the students become. Just as my male student who berated me needed to put me down, I feel l've discovered the trick to popularity in the first-year classroom involves some domination. It's as if they want to play masochist, and if they don't get to, they lash out at my refusal to play the game.

Thinking about my performing as a professor takes me back to the ball scene. In Paris Is Burning, one particularly compelling competition involves "schoolgirl realness," with boys wearing collegiate women's outfits, complete with books. ${ }^{22}$ What is professorial "realness"? In terms of style, it may be hard to pinpoint, although my first year Contracts professor was an inspiration. A petite Asian woman, she wore her hair short and boys' suits and ties to match. "Butching it up" was a successful performance of professorial realness from someone in whom many students would not invest professorial credibility due to her sex, age, and size. My professorial "realness," like my professor and the schoolgirl realness queens, is not about self-expression, but performance. ${ }^{23}$ It surfaces more in my newfound strictness and my reliance on a modified Socratic method than it does in my suits and ties.

These performances in our microcosm reflect a broader continued dominion of traditional gender roles. A recent study in the Journal of Applied Psychology points out that the wage gap between men and women is mean-

20 Patricia Williams, Alchemy of Race and Rights: Diary of a Law Professor 146-49 (1991); Chang \& Davis, supra note 8, at 5.

${ }^{21}$ Williams, supra note 20.

${ }^{22}$ Paris is Burning, supra note 1.

${ }^{23}$ If I were to engage in self-expression, I might be drawn to returning to the skirts and dresses I wore as a student at Penn, where I even went to a formal event in drag. The then-Dean supposedly remarked, "Who is that woman? She's awfully masculine." 
ingfully related to the individual's belief in traditional gender roles. ${ }^{24}$ Men who believe in traditional roles, that is to say, men who do not believe in women's rights, earn the most, while women who believe in traditional roles earn the least. ${ }^{25}$ The difference between men and women who do not believe in traditional gender roles was relatively minor. ${ }^{26}$ The study says that sexist men earn more than men who believe in gender equality. ${ }^{27}$ Women who believe in gender equality earn more than women who adhere to a traditional role. ${ }^{28}$ Thus, men and women, both with traditional gender role views, in the same occupation, have a huge gap in salary. In contrast, men and women in the same occupation believing in gender equality do not have such a gap. In short, as a male it pays to be traditionally gendered, and I shifted my firstyear class performance to match this understanding. By this, it's worth noting, I mean that I take control of the classroom, not that I necessarily behave in some outlandishly butch performance.

My engagement in traditional law school pedagogy, despite the extent to which it may upend feminist norms, makes me think twice about the efficacy of equality-centered rule setting. For me, it reflects the extent to which awareness of identity may not actually further protection from discrimination. As Ramachandran argues:

The fact that identity performance is so contextual and complex makes it hard, if not impossible, to formulate legal rules for protecting identity performance under the traditional equality-based rubrics of antidiscrimination law. To do so would require isolating which identity performances constitute the performance of a protected identity category and which do not $\ldots{ }^{29}$

The inflexibility of legal rules' capacity to bend to meet varying identity performances only lends further support to critical assessments of the need for social and cultural changes, rather than simply formalistic legal ones.

Before concluding, I want to make two more points, one about class, and one about the persistence of old-fashioned harassment. First, class. Adrienne, you say "we need to generate more complex accounts of power." 30 It merits mentioning that neither you nor I would exclude class and status from that conversation, even if we sport Lanvin as we converse. We academics, even those of us who recognize the subjectivity in scholarship, often subscribe to objective understandings of our work. We disassociate our work from its social and political effects, and more importantly, we think of

${ }^{24}$ Timothy A. Judge \& Beth A. Livingston, Is the Gap More Than Gender? A Longitudinal Analysis of Gender, Gender Role Orientation, and Earnings, 93 J. App. Pysch. 994 (2008).

${ }^{25}$ Id.

${ }^{26} I d$.

${ }^{27} I d$.

${ }^{28} / d$.

${ }^{29}$ Ramachandran, supra note 4, at 23.

${ }^{30}$ Chang \& Davis, supra note 8 , at 47. 
ourselves as not belonging to an economic class. ${ }^{31}$ We do spend much of our time on scholarship that has no direct economic value, unlike my billing time to mega-clients. But we should not close our eyes to the critical role that our gate-keeper function plays in maintaining an economic structure whose success depends in part on the prominence of juridical norms. Even as law professors, we sit squarely inside the class structure. For better or worse, I would imagine that the iterations of bias depend on the class of the individual whose bias is at issue. This all-too-common self-perception may color our ability to understand our students' behavior with regard to other forms of difference.

And, although our egalitarian conversations matter, we must recall that within the institutions where we work, we have a relatively high status. Our students do not. This became pellucid for me when I was recently in Santiago, Chile and saw the University of Chile Faculty of Law literally under siege by student protesters who objected, in part, to standards for the hiring of professors. Student chairs were piled up at the law school gates, blocking entry to anyone except the student protest organizers. Melissa Murray's essay on Duncan Kennedy reminds me of this status distinction. ${ }^{32}$ In that piece, she points out the contradictions in Kennedy's locating potential resistance to hierarchy among the students even though they sit near the bottom of the law school hierarchy. ${ }^{33}$ We are vulnerable, as your exchange demonstrates, but let's not presume our students' invulnerability.

I close with a tale of persistence. Not my own, but that of insidious, bald-faced, bias-driven harassment. The class whose evaluations I discuss above graduated from Pace Law School in May 2007. At that point I was the only openly gay professor on the full-time faculty (at the time I began at Pace in 2004, there were two of us). Shortly after those graduating students took the Bar, I received three messages on my work voicemail left by a man saying variations of "faggot, fucking faggot" in a gravelly whisper. ${ }^{34}$ The authorities (at Pace and at the White Plains Police Department) could not trace the number. Other contemporaneous incidents of bias erupted at Pace's main campus. They involved racial and religious epithets and received substantial public attention and targeted efforts to avert repeat incidents. Mine

${ }^{31}$ The perfect example of this self-perception among professors is in a long conversation I had with a professor when I was an associate at Skadden in late 2001 in New York. We were talking about targets for terrorists and how the World Trade Center may have been selected because of its symbolic role in U.S. economic imperialism. At the time, I was sometimes nervous working in a prominent building in Times Square, having recently seen the second plane hit with my own eyes. This prominent academic told me that I was directly engaged in capitalist production (as a corporate lawyer), while he claimed not to be.

${ }^{32}$ Melissa Murray, "I'd Like to Thank the Academy": Eminem, Duncan Kennedy and the Limits of Critique, 55 J. LEGAL ED. 65 (2005).

${ }^{33} \mathrm{Id}$. at 78 . Law school staff fit into many different slots in the hierarchy. In our institution, like many others, the cleaning staff sit in the most fragile class position.

${ }^{34} \mathrm{I}$ do not know if any of these students had any involvement in the harassing messages, but the timing arouses my suspicions. 
passed quietly, even though I was the only faculty member to be targeted by any of these incidents. My dear friend and colleague Bridget Crawford suggested a public faculty statement against homophobia, but I was up for reappointment and hesitated to draw attention to my plight. At lunch near campus, a tolerant senior colleague of mine told me it would be bad for Pace's image if the incidents made it into the press. I let the incidents pass.

The same harasser called again this past academic year. I was in the process of applying for tenure. The Dean supported me, as did the staff, in attempting to pursue the case, but again, the caller could not be identified. I could have continued fighting for attention to such naked homophobia or used the incident to militate for broader changes to foster civility in the face of difference. I could have engaged a very supportive colleague as my advocate. I could have ... but did not. A close friend counseled me that to invest all my energy in fighting this homophobia would allow them to make me into a victim. I' $m$ not sure I made the right decision, but it's done and I am thankful that this drama arose at a more sure-footed point in my academic career.

Kenji Yoshino refers to where he works as a "vigorously progay environment," a moniker that many presume to apply to the entire legal academy. ${ }^{35}$ My experience suggests that his description may describe Yale Law School accurately but not necessarily much more of our world. ${ }^{36}$ Yoshino argues that civil rights efforts should move to engage more subtle forms of discrimination such as "covering" as the next challenging area of the law, but l'd add that such efforts should not supplant combating old-fashioned bias. For all our presumptions of progress, bias-driven harassment persists. ${ }^{37}$ It persists despite our efforts, and despite the efforts of those who came before us. It persists even at overwhelmingly liberal institutions. We've all suffered ignominies and insults, both subtle and overt, those we battle and those we internalize. Perhaps the only conclusion to draw is that to fight such mean-spiritedness, we must force ourselves to drop our professional objectivity masks and engage in conversations like these, Adrienne and Bob. (2006).

${ }^{35}$ Kenji Yoshino, Covering: The Singular Assault on Our Civil Rights 17

${ }^{36}$ I concur with Yoshino that being a "homosexual professional" is a more assured route to success than being a "professional homosexual." Id. I disagree, however, with the implication that this form of covering pressure is the only discrimination LGBT people face.

${ }^{37}$ Id. at 25 . 
Afterward, as we head back to our institutions and students, perhaps you too can find inspiration in that old queen Albin who deploys a cheap and easy remedy for life's ills in La Cage Aux Folles:

So whenever I feel that my place in the world is beginning to crash,

I apply one great stroke of Mascara to my rather limp upper lash. And I can cope again, Good God! There's hope again!

When life is a real bitch again, and my old sense of humor has up, and gone

It's time for the big switch again, I put a little more Mascara on..$^{38}$

In sisterhood,

Darren

${ }^{38}$ La CaGe Aux Folles (Da Ma Produzione 1973). 